\title{
Errors and improvements in the use of archived meteorological data for chemical transport modeling: an analysis using GEOS-Chem v11-01 driven by GEOS-5 meteorology
}

\author{
Karen Yu ${ }^{1}$, Christoph A. Keller ${ }^{2,3}$, Daniel J. Jacob ${ }^{1,4}$, Andrea M. Molod ${ }^{3}$, Sebastian D. Eastham ${ }^{1}$, and \\ Michael S. Long ${ }^{1}$ \\ ${ }^{1}$ School of Engineering and Applied Sciences, Harvard University, Cambridge, MA, USA \\ ${ }^{2}$ Universities Space Research Association, Columbia, MD, USA \\ ${ }^{3}$ NASA Goddard Space Flight Center, Greenbelt, MD, USA \\ ${ }^{4}$ Department of Earth and Planetary Sciences, Harvard University, Cambridge, MA, USA
}

Correspondence: Karen Yu (kyu@ seas.harvard.edu)

Received: 20 May 2017 - Discussion started: 6 July 2017

Revised: 24 November 2017 - Accepted: 8 December 2017 - Published: 23 January 2018

\begin{abstract}
Global simulations of atmospheric chemistry are commonly conducted with off-line chemical transport models (CTMs) driven by archived meteorological data from general circulation models (GCMs). The off-line approach has the advantages of simplicity and expediency, but it incurs errors due to temporal averaging in the meteorological archive and the inability to reproduce the GCM transport algorithms exactly. The CTM simulation is also often conducted at coarser grid resolution than the parent GCM. Here we investigate this cascade of CTM errors by using ${ }^{222} \mathrm{Rn}-{ }^{210} \mathrm{~Pb}-{ }^{7} \mathrm{Be}$ chemical tracer simulations off-line in the GEOS-Chem CTM at rectilinear $0.25^{\circ} \times 0.3125^{\circ}(\approx 25 \mathrm{~km})$ and $2^{\circ} \times 2.5^{\circ}(\approx 200 \mathrm{~km})$ resolutions and online in the parent GEOS-5 GCM at cubed-sphere $\mathrm{c} 360(\approx 25 \mathrm{~km})$ and $\mathrm{c} 48$ $(\approx 200 \mathrm{~km}$ ) horizontal resolutions. The $\mathrm{c} 360$ GEOS-5 GCM meteorological archive, updated every $3 \mathrm{~h}$ and remapped to $0.25^{\circ} \times 0.3125^{\circ}$, is the standard operational product generated by the NASA Global Modeling and Assimilation Office (GMAO) and used as input by GEOS-Chem. We find that the GEOS-Chem ${ }^{222} \mathrm{Rn}$ simulation at native $0.25^{\circ} \times 0.3125^{\circ}$ resolution is affected by vertical transport errors of up to $20 \%$ relative to the GEOS-5 c360 online simulation, in part due to loss of transient organized vertical motions in the GCM (resolved convection) that are temporally averaged out in the $3 \mathrm{~h}$ meteorological archive. There is also significant error caused by operational remapping of the meteorological archive from a cubed-sphere to a rectilinear grid. Decreasing the GEOS-Chem resolution from $0.25^{\circ} \times 0.3125^{\circ}$
\end{abstract}

to $2^{\circ} \times 2.5^{\circ}$ induces further weakening of vertical transport as transient vertical motions are averaged out spatially and temporally. The resulting ${ }^{222} \mathrm{Rn}$ concentrations simulated by the coarse-resolution GEOS-Chem are overestimated by up to $40 \%$ in surface air relative to the online $\mathrm{c} 360$ simulations and underestimated by up to $40 \%$ in the upper troposphere, while the tropospheric lifetimes of ${ }^{210} \mathrm{~Pb}$ and ${ }^{7} \mathrm{Be}$ against aerosol deposition are affected by 5-10\%. The lost vertical transport in the coarse-resolution GEOS-Chem simulation can be partly restored by recomputing the convective mass fluxes at the appropriate resolution to replace the archived convective mass fluxes and by correcting for bias in the spatial averaging of boundary layer mixing depths.

\section{Introduction}

Accurate simulation of transport is crucial for global models of atmospheric composition. Transport information is provided by general circulation models (GCMs) that solve the conservation equations for air mass, momentum, heat, and water and may assimilate meteorological observations to reproduce a specific period. GCMs compute grid-resolved winds, sub-grid turbulence, and convection properties that determine the transport of chemical species through the corresponding continuity equations (Brasseur and Jacob, 2017). These equations can be solved "online" as part of the GCM or 
"off-line" by using archived winds and turbulence statistics to drive a separate chemical transport model (CTM). The offline approach has the advantages of simplicity and economy, but it introduces differences due to temporal (and sometimes spatial) averaging in the meteorological archive and due to inability to exactly replicate the GCM transport algorithms. Since the CTM aims to replicate the original transport of the GCM, any deviation from the GCM transport can be viewed as an error. Here we use chemical tracers to investigate the cascade of errors involved in successively degrading a global online simulation with high spatial resolution through various stages to an off-line simulation with coarse horizontal spatial resolution and coarse temporal resolution of input data.

Whether online or off-line, a model of atmospheric composition computes the concentrations of atmospheric species by solving the relevant chemical continuity (mass conservation) equations. In an Eulerian (fixed frame of reference) framework,

$$
\frac{\partial \rho_{i}}{\partial t}=-\nabla \cdot\left(\rho_{i} \boldsymbol{v}\right)+\nabla \cdot\left(\mathbf{K} \rho_{\mathrm{a}} \nabla \frac{\rho_{i}}{\rho_{\mathrm{a}}}\right)+P_{i}-L_{i} .
$$

Here $\rho_{i}$ is the mass density of species $i, \rho_{\mathrm{a}}$ is the air density, $\boldsymbol{v}$ is the wind vector, $\nabla \cdot\left(\rho_{i} \boldsymbol{v}\right)$ represents the advection term (flux divergence), and $P_{i}-L_{i}$ accounts for local production and loss from chemical reactions. Small-scale turbulent transport is parameterized in Eq. (1) as an eddy diffusion term where $\mathbf{K}$ is an eddy diffusivity tensor. Additional parameterizations are applied for convection, which is sub-grid on the horizontal scale but organized (nonlocal) on the vertical scale. Unlike the Navier-Stokes conservation equation for momentum, where nonlinear dependence on momentum introduces chaos in the solution, the chemical continuity equation has stable solutions when $\boldsymbol{v}$ and $\mathbf{K}$ are specified. This is an important motivation for decoupling the CTM from the GCM and using archives of $\boldsymbol{v}, \mathbf{K}$, and convection diagnostics to drive the off-line transport.

A GCM typically uses a time step of the order of minutes to integrate the conservation equations for atmospheric dynamics. In an online model, the chemical continuity equations can be integrated using updated winds on the same time step. But archiving winds at that resolution for off-line CTM applications is impractical in terms of data storage. Instead, meteorological archives for use in CTMs are typically available as temporal averages every few hours, losing information on eddy motions on shorter timescales that might affect chemical transport. Rasch et al. (1997) found that $6 \mathrm{~h}$ archiving of GCM meteorological fields did not induce significant off-line chemical transport error but $24 \mathrm{~h}$ archiving did. Dentener et al. (1999) confirmed that CTMs using meteorology archived at $6 \mathrm{~h}$ intervals could reproduce the transport of the originating GCM. These older GCMs used grid resolutions of hundreds of kilometers, whereas current GCMs use tens of kilometers. The error from temporal averaging increases with increasing grid resolution, particularly as the GCM be- comes fine enough to partly resolve convective scales (Grell et al., 2004).

Deep convection is of particular concern for off-line CTM applications. Vertical convective motions driven by buoyancy are sub-grid on the horizontal scale but organized on the vertical scale, transporting air across several vertical model levels in a single time step. Deep convection enables the transport of short-lived species to high altitudes and scavenges water-soluble species (such as aerosol particles) in the cloud updrafts. Convective parameterizations used in GCMs diagnose cloud updrafts, downdrafts, detrainment and entrainment, and compensatory large-scale subsidence on the grid scale (Brasseur and Jacob, 2017). It is common practice to use temporally averaged convective mass fluxes from the GCM archives to drive off-line models, but the exact timing of events is then lost. A compounding problem is that current GCMs have sufficiently fine resolution to partly resolve convective systems on the grid scale, so the parameterized convection is suppressed in scale-aware schemes (Grell and Freitas, 2014; Molod et al., 2015). Typical convective systems persist for less than $1 \mathrm{~h}$, and the corresponding advective transport is averaged out in a multi-hour wind archive.

Spatial averaging of the meteorological archive is yet another concern. CTM simulations of oxidant-aerosol chemistry and/or aerosol microphysics may require over 100 coupled species. The computational costs are large. A way to reduce costs is to degrade spatial resolution. It is thus common practice in CTM applications to average the GCM meteorological fields onto coarser grids for input to the CTM and operate the CTM at that coarser resolution. But the averaging may introduce transport biases. For example, vertical eddy fluxes resolved at the native $0.25^{\circ} \times 0.3125^{\circ} \mathrm{GCM}$ resolution may be lost by averaging to the coarser grid.

Here we examine how the off-line archiving of GCM meteorological data, including temporal and spatial averaging, affects the simulation of transport in the GEOS-Chem CTM, and we recommend some corrections for these errors. We use for this purpose the ${ }^{222} \mathrm{Rn}-{ }^{210} \mathrm{~Pb}-{ }^{7} \mathrm{Be}$ tracer suite, which provides a standard basis for evaluating transport and aerosol scavenging in CTMs (Jacob et al., 1997; Liu et al., 2001; Considine et al., 2005; Zhang et al., 2017). The GEOS-Chem CTM, originally described by Bey et al. (2001), is an opensource global model of atmospheric composition used by a large research community for a wide range of applications. The experiments described here rely on assimilated meteorological data archived every $3 \mathrm{~h}$ from the NASA Goddard Earth Observation System (GEOS) Data Assimilation System (DAS; Rienecker et al., 2011; Gelaro et al., 2017) on a cubed-sphere grid interpolated to $0.25^{\circ} \times 0.3125^{\circ}(\approx 25 \mathrm{~km})$ horizontal resolution. The GEOS DAS uses the underlying GCM described in Rienecker et al. (2008) and Molod et al. (2015). GEOS-Chem CTM simulations can be conducted at that native resolution, but global simulations generally use degraded $2^{\circ} \times 2.5^{\circ}(\approx 200 \mathrm{~km})$ resolution for computational expediency. The GEOS-Chem chemical module (solv- 
ing $\frac{\partial \rho_{i}}{\partial t}=P_{i}-L_{i}$ ) has recently been integrated within the GEOS GCM so that simulations with detailed chemistry can be conducted either online or off-line using the exact same module (Long et al., 2015).

\section{Model descriptions}

\subsection{GEOS-5 GCM}

The Goddard Earth Observing System Model version 5 (GEOS-5) is a GCM developed by the NASA Global Modeling and Analysis Office (GMAO) (Rienecker et al., 2008; Molod et al., 2015). Advection is driven by the finite-volume dynamical core of Putman and Lin (2007), which uses sub-stepping to ensure that the Courant number does not exceed unity. Boundary layer mixing is based on the nonlocal scheme of Lock et al. (2000) and the Richardson-number-based scheme of Louis et al. (1982). The convective parameterization is the Relaxed Arakawa-Schubert (RAS) scheme (Moorthi and Suarez, 1992) with a scheme for the generation and reevaporation of precipitation (Bacmeister et al., 2006). RAS computes the effect of multiple individual cloud plumes released sequentially using a resolution-dependent stochastic trigger function (Bacmeister and Stephens, 2011). GEOS-5 has 72 vertical levels up to $0.01 \mathrm{hPa}$ on a hybrid eta (sigmapressure) grid. The horizontal grid is cubed-sphere (Putman and Lin, 2007) and can operate at a range of resolutions. The integration of the model equations on the cubed-sphere grid eliminates the problem of large Courant numbers near the poles and permits straightforward domain decomposition for distributed-memory environments. The cubed-sphere grid has been used in other GCMs, such as the Geophysical Fluid Dynamics Laboratory (GFDL) Atmospheric Model 3 (AM3) (Donner et al., 2011).

We use here the operational GEOS-5 product (https: //gmao.gsfc.nasa.gov/GMAO_products/NRT_products.php) generated at a cubed-sphere c360 $(\approx 25 \mathrm{~km})$ horizontal resolution. The data combines the GEOS-5 GCM with observations using a hybrid ensemble Kalman filter threedimensional variational (3D-Var hybrid) system (Rienecker et al., 2012). The internal GCM time step for advection and convection is $7.5 \mathrm{~min}$. Output from the c360 simulation is mapped onto a $0.25^{\circ} \times 0.3125^{\circ}$ latitude $\times$ longitude rectilinear grid to produce the GEOS forward-processing (GEOSFP) archive released operationally by GMAO. The archived data relevant to CTM transport and scavenging include 3-D winds, convective mass fluxes, precipitation fields, and 2-D surface pressures and boundary layer mixing depths. The 3 -D data are archived as $3 \mathrm{~h}$ averages and the 2-D data as $1 \mathrm{~h}$ averages.

GEOS operational meteorological products have been widely used for off-line CTM applications including by the University of Maryland (UMD) CTM (Allen et al., 1996),
GEOS-Chem (Bey et al., 2001), Global Modeling Initiative (GMI) CTM (Douglass et al., 1999, 2004), Integrated Massively Parallel Atmospheric Chemical Transport (IMPACT) model (Rotman et al., 2004), MOZART (Emmons et al., 2010), CAM-Chem (Lamarque et al., 2012), and the GEOS CTM (Kouatchou et al., 2015). Chemical transport simulations can also be performed online within the GEOS-5 GCM (Colarco et al., 2010; Oman and Douglass, 2014; Long et al., 2015; Strode et al., 2015; Li et al., 2016). Although we use GEOS-Chem in our comparisons against online GEOS5 GCM results, the issues discussed in this paper are more generally pertinent to CTMs driven by archived GCM meteorological data.

\subsection{GEOS-Chem CTM}

We use two versions of GEOS-Chem: the standard version 11-01 released in February 2017 (http://wiki.seas. harvard.edu/geos-chem/index.php/GEOS-Chem_v11-01) and a beta high-performance version (GCHP) designed for massively parallel computing environments (http://wiki.seas. harvard.edu/geos-chem/index.php/GEOS-Chem_HP). The standard GEOS-Chem operates on the rectilinear grid from the GEOS-5 archive, while GCHP operates on the GEOS-5 cubed-sphere grid. Both versions use the same archived meteorological data and modules except for advection. GCHP uses an off-line version of the same Putman and Lin (2007) dynamical core as GEOS-5, while the standard GEOS-Chem uses a dynamical core developed for off-line applications on a rectilinear grid (Lin and Rood, 1996). The Lin and Rood (1996) scheme averages winds, surface pressures, and mixing ratios over the two highest latitude bands to compensate for the polar singularity. Vertical advection is computed in both cases from the change in surface pressure, but vertical advection in the standard rectilinear GEOS-Chem is lower order than in GEOS-5 and GCHP. In the standard rectilinear GEOS-Chem, a pressure fixer (Horowitz et al., 2003) is used to correct for inconsistencies between horizontal wind divergence and pressure tendencies resulting from the temporal averaging in the meteorological archive, whereas GCHP enforces mass consistency by applying a global scaling factor.

Convective transport in GEOS-Chem is simulated with a single-plume scheme using the archived $3 \mathrm{~h}$ net updraft and detrainment convective mass fluxes summing over all RAS plumes within a given grid column (Wu et al., 2007). Although GEOS-Chem reproduces the bulk $3 \mathrm{~h}$ convective transport in the GEOS-5 GCM, the precise timing and interactions between RAS convective plumes are not resolved since that information is not in the archive. Bulk convective transport using archived mass fluxes is a standard procedure in other CTMs driven by GEOS-5 meteorology, such as the GMI CTM, and CTMs driven by other meteorology, such as TOMCAT (Feng et al., 2011, driven by ECMWF reanalysis data). 
Boundary layer mixing in GEOS-Chem uses the nonlocal parameterization of Holtslag and Boville (1993) adapted for GEOS-Chem by Lin and McElroy (2010). It draws on the archived GEOS-5 mixing depths, temperature, latent and sensible heat fluxes, and specific humidity. The mixing depths in the GEOS-5 archive are a diagnostic quantity, and thus boundary layer mixing in GEOS-Chem may differ from that in the GEOS-5 GCM.

GEOS-Chem applications typically use the native horizontal resolution of the GEOS products for nested simulations over continental-scale domains (Wang et al., 2004; Chen et al., 2009; Kim et al., 2015) but a coarser $2^{\circ} \times 2.5^{\circ}$ horizontal resolution for global simulations. The $2^{\circ} \times 2.5^{\circ}$ meteorological archive is generated by averaging the original GEOS5 archive over the corresponding grid. As part of this work, we developed a capability to conduct global GEOS-Chem simulations for passive tracers at native $0.25^{\circ} \times 0.3125^{\circ}$ horizontal resolution. This allows us to separate the contributions of off-line archiving and degraded resolution to model errors.

\section{Simulation ensemble}

\subsection{The ${ }^{222} \mathrm{Rn}-{ }^{210} \mathrm{~Pb}-{ }^{7} \mathrm{Be}$ system}

The natural tracer suite ${ }^{222} \mathrm{Rn}-{ }^{210} \mathrm{~Pb}-{ }^{7} \mathrm{Be}$ provides a standard test of vertical transport and scavenging in global models, with capability to compare to observations (Liu et al., 2001). ${ }^{222} \mathrm{Rn}$ is emitted ubiquitously by soils. Its sole sink is radioactive decay to ${ }^{210} \mathrm{~Pb}$ with a half-life of 3.8 days, making it a sensitive tracer for vertical transport in the troposphere (Liu et al., 1984; Jacob and Prather, 1990; Jacob et al., 1997; Allen et al., 1996). ${ }^{210} \mathrm{~Pb}$ (half-life 22.3 years) attaches to aerosol particles and provides a diagnostic for aerosol lifetime against deposition (Balkanski et al., 1993). ${ }^{7} \mathrm{Be}$ (half-life 53.3 days) is produced in the upper troposphere and lower stratosphere from the interaction of cosmic rays with atmospheric oxygen and nitrogen (Lal and Peters, 1967) and attaches to aerosol particles and is removed by deposition in the same way as ${ }^{210} \mathrm{~Pb}$. The high-altitude source of ${ }^{7} \mathrm{Be}$ complements ${ }^{210} \mathrm{~Pb}$ by testing the model representation of subsidence and stratosphere-troposphere exchange (Koch et al., 1996; Considine et al., 2005).

Here we use the ${ }^{222} \mathrm{Rn}-{ }^{210} \mathrm{~Pb}-{ }^{7} \mathrm{Be}$ simulation originally developed for GEOS-Chem by Liu et al. (2001). ${ }^{222} \mathrm{Rn}$ is emitted uniformly from land excluding ice at a rate of 1.0 atoms cm $\mathrm{cm}^{-2} \mathrm{~s}^{-1}$ under nonfreezing conditions and 0.3 atoms $\mathrm{cm}^{-2} \mathrm{~s}^{-1}$ under freezing conditions. The ${ }^{7} \mathrm{Be}$ source function depends only on altitude and latitude. ${ }^{210} \mathrm{~Pb}$ and ${ }^{7} \mathrm{Be}$ are removed by aerosol wet and dry deposition, in addition to radioactive decay (negligible for ${ }^{210} \mathrm{~Pb}$ ). Dry deposition is a minor sink. Wet deposition includes scavenging in convective updrafts following the approach of Balkanski et al. (1993), and first-order in-cloud and below-cloud scav- enging for anvil and large-scale (grid-resolved) precipitation following the approach of Giorgi and Chameides (1986). Aerosol can be released below cloud if precipitation evaporates. The scavenging parameterizations of Liu et al. (2001) are intended to be applicable to GEOS-Chem at all resolutions because convective mass fluxes (from the GEOS-5 archive) do not change with resolution and because firstorder rainout or washout assumes precipitating fractions of grid boxes that are set in all cases by a fixed rate of conversion of cloud water to precipitation (Giorgi and Chameides, 1986).

A recent study by Zhang et al. (2017) uses GEOS-Chem with an updated ${ }^{222} \mathrm{Rn}$ source function to evaluate with observations worldwide. Here our focus is not on comparison to observations but on the effect of CTM model differences relative to a reference simulation. Since the averaging and remapping of meteorological fields in the CTM represents a degradation of the information from the reference simulation, we view for our purpose the reference simulation as the "truth" against which the different CTM simulations can be compared.

\subsection{Simulations performed}

We conducted a number of online and off-line ${ }^{222} \mathrm{Rn}-{ }^{210} \mathrm{~Pb}-$ ${ }^{7} \mathrm{Be}$ simulations for different spatial resolutions and configurations, as illustrated in Figure 1 and explained below. All simulations were conducted for 2 months starting from zero concentrations on 1 June 2013. We report and compare monthly mean results for July 2013 after a 1-month (June) spin-up. We limited the analysis to 1 month because of computational and storage requirements for the high-resolution simulations and with the expectation that 1 month in Northern Hemisphere summer is a sufficient time window to diagnose systematic differences in vertical tropospheric transport as revealed by the ${ }^{222} \mathrm{Rn}-{ }^{210} \mathrm{~Pb}-{ }^{7} \mathrm{Be}$ system. The zero initialization allows for sensitive analysis of differences but implies that concentrations are not in steady state and should not be compared to observations, in particular for ${ }^{210} \mathrm{~Pb}$ and ${ }^{7} \mathrm{Be}$. For example, observed and steady-state GEOS-Chem ${ }^{210} \mathrm{~Pb}$ concentrations in the stratosphere are higher than in the troposphere (Liu et al., 2001), but in our simulations they are much lower. Stratospheric concentrations of ${ }^{222} \mathrm{Rn}$ and ${ }^{210} \mathrm{~Pb}$ should not be compared across simulations since the injection of ${ }^{222} \mathrm{Rn}$ into the stratosphere may be driven by sporadic deep convection (Lambert et al., 1990). The stratosphere is not discussed in what follows.

Simulation 1 is conducted online using a version of GEOS-5 similar to the one used in Molod et al. (2015) at c360 resolution. For ${ }^{222} \mathrm{Rn}$, it defines the reference simulation; all other simulations in Fig. 1 (blue boxes) successively degrade some aspect of that reference simulation. This is not the case for ${ }^{210} \mathrm{~Pb}$ and ${ }^{7} \mathrm{Be}$ because the scheme for aerosol wet scavenging in the GEOS-5 GCM is less advanced than in GEOS-Chem. In particular, aerosol scavenging in the GCM 


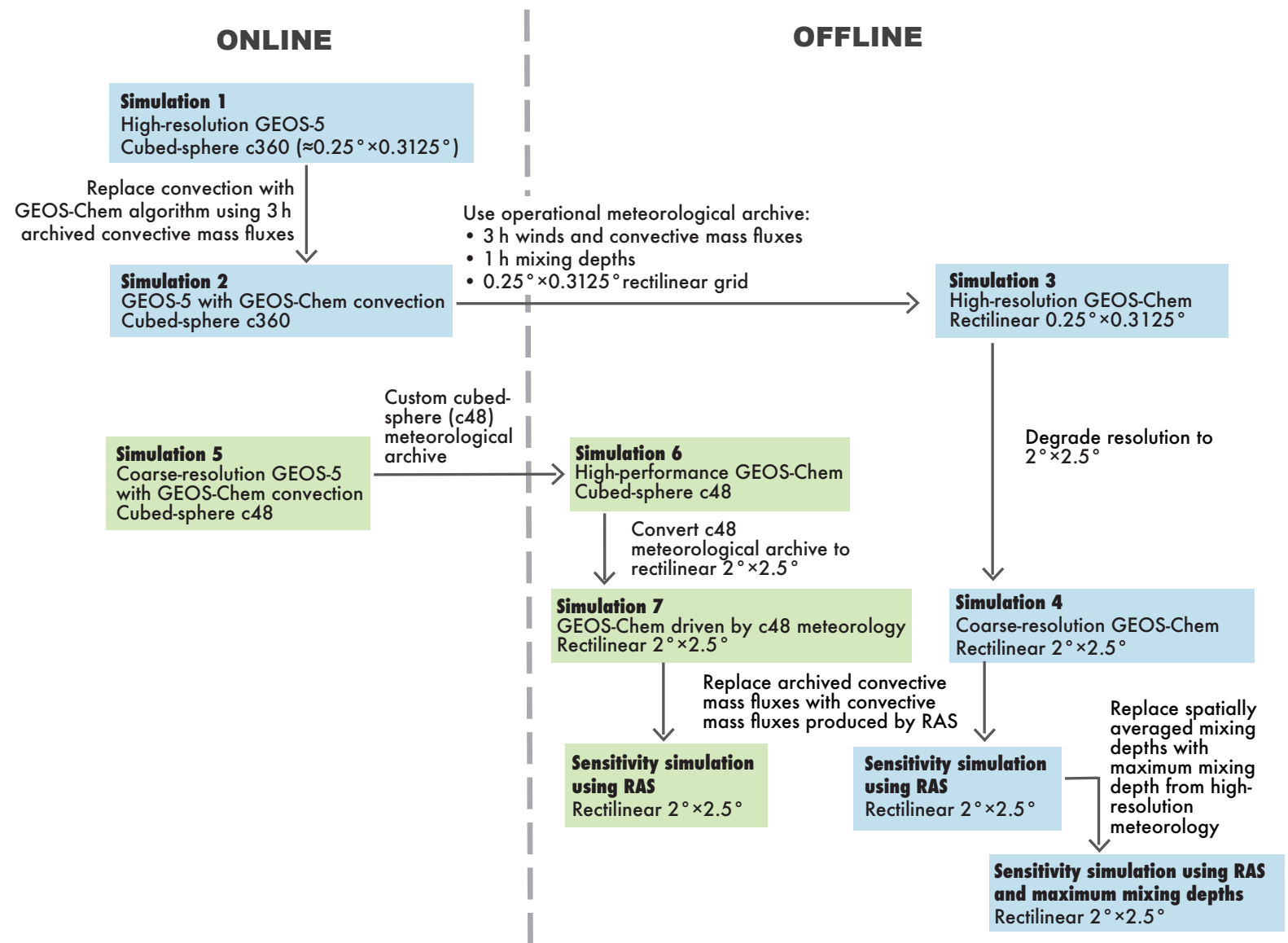

Figure 1. Ensemble of global ${ }^{222} \mathrm{Rn}-{ }^{210} \mathrm{~Pb}-{ }^{7} \mathrm{Be}$ simulations conducted in this work. The blue and green boxes identify simulations originating from reference high-resolution (c360) and coarse-resolution (c48) GEOS-5 meteorological products, respectively.

is not coupled to sub-grid transport in deep convective updrafts, and this can severely overestimate the transport of aerosols to the upper troposphere (Balkanski et al., 1993). Thus we do not show ${ }^{210} \mathrm{~Pb}$ and ${ }^{7} \mathrm{Be}$ results from the online simulations.

Simulation 2 is also conducted online at c360 resolution but with the bulk convective algorithm of GEOS-Chem and $3 \mathrm{~h}$ averaged convective mass fluxes from simulation 1 . This allows us to separately examine the effect of using archived fields on convection and advection. Simulation 2 is used to generate the meteorological archive ( $3 \mathrm{~h}$ for winds and convective mass fluxes, $1 \mathrm{~h}$ for mixing depths) for the off-line GEOS-Chem simulations. This off-line archive mimics the operational GEOS-FP archive by using the same temporal averaging windows and remapping the cubed-sphere meteorological data to a $0.25^{\circ} \times 0.3125^{\circ}$ rectilinear grid.

Simulation 3 is the standard off-line high-resolution GEOS-Chem on a $0.25^{\circ} \times 0.3125^{\circ}$ rectilinear grid. It uses an archive of winds, mixing depths, and convective mass fluxes generated from simulation 2 that mimics the GEOS-5 operational product. Errors in the ${ }^{222} \mathrm{Rn}$ simulation compared to simulation 2 include the temporal averaging of winds and mixing depths, the remapping of the meteorological archive to a rectilinear grid, and the use of a lower-order advection core and a different boundary layer mixing scheme. For ${ }^{210} \mathrm{~Pb}$ and ${ }^{7} \mathrm{Be}$, simulation 3 represents our best-case reference simulation.

Simulation 4 is the standard off-line coarse-resolution GEOS-Chem on a $2^{\circ} \times 2.5^{\circ}$ grid. It uses the off-line meteorological archive from simulation 2 but degraded to $2^{\circ} \times 2.5^{\circ}$ resolution. Comparison with simulation 3 shows the error from degraded horizontal resolution. Comparison to simulation 1 (for ${ }^{222} \mathrm{Rn}$ ) shows the compounded errors in going from the original online GEOS-5 simulation to the off-line, coarse-resolution simulation.

Although global GEOS-Chem simulations may be conducted at coarse $2^{\circ} \times 2.5^{\circ}$ resolution, they use driving meteorological fields generated from the original GEOS-5 simulation at $\mathrm{c} 360\left(\approx 0.25^{\circ} \times 0.3125^{\circ}\right)$ resolution. This is an important distinction from a simulation that would be driven by a coarser meteorological model. To investigate that effect, we also conducted an online simulation 5 using GEOS5 meteorology at $\mathrm{c} 48$ resolution $\left(\approx 2^{\circ} \times 2.5^{\circ}\right)$. We then used the meteorological data from simulation 5 , archived on the 

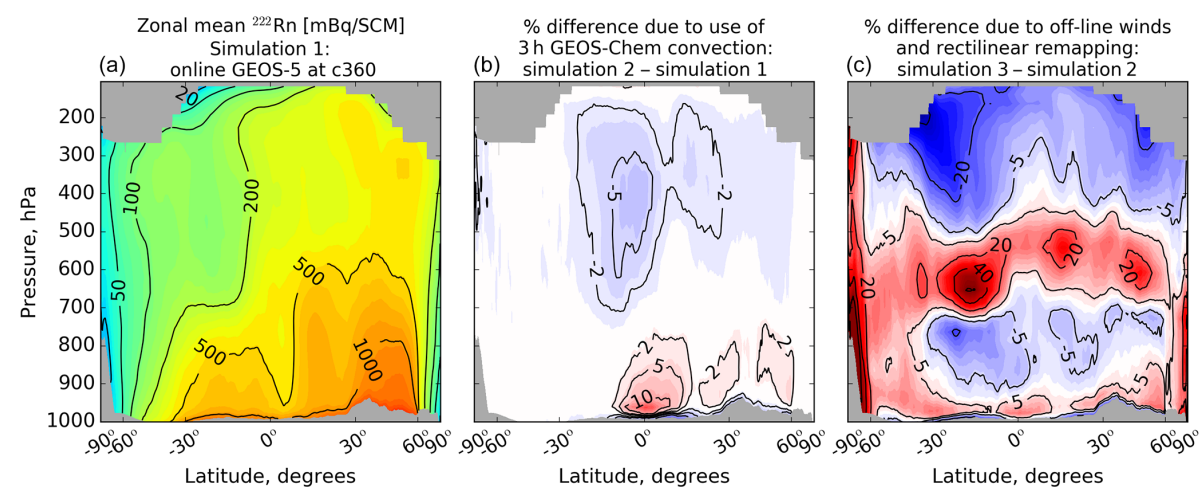

Figure 2. Off-line transport errors in ${ }^{222} \mathrm{Rn}$ concentrations simulated at $\mathrm{c} 360(\approx 25 \mathrm{~km})$ resolution. (a) Zonal mean concentrations of ${ }^{222} \mathrm{Rn}$ from the online GEOS-5 reference simulation with c360 cubed-sphere resolution (simulation 1). Values are monthly means for July 2013 after a 1-month spin-up from zero concentrations and are expressed in mixing ratio units of millibecquerels per standard cubic meter (at $0^{\circ} \mathrm{C}$ and $1 \mathrm{~atm}$ pressure) or $\mathrm{mBq} \mathrm{SCM}^{-1}$. (b) Errors due to the use of simplified off-line GEOS-Chem convection shown as percentage differences between simulation 2 and simulation 1. (c) Errors in the high-resolution GEOS-Chem simulation at $0.25^{\circ} \times 0.3125^{\circ}(\approx 25 \mathrm{~km})$ resolution due to off-line archiving of winds and mixing depths, remapping to rectilinear grid, and use of different transport schemes shown as percentage differences between simulation 3 and simulation 2. The abscissa is on a sine latitude (equal area) scale. Stratospheric results are not shown (see text). Here and in other figures, solid color contours provide finer gradation of the labeled line contours.

cubed-sphere grid, to drive an off-line c48 simulation using the high-performance version of GEOS-Chem on that grid (simulation 6) and an off-line $2^{\circ} \times 2.5^{\circ}$ simulation using the standard GEOS-Chem on a rectilinear grid (simulation 7). A comparison of simulations 6 and 7 diagnoses the error from remapping the meteorological archive from its native cubedsphere to a rectilinear grid. Except for temporal averaging, the off-line archive for simulation 6 is fully consistent with the $\mathrm{c} 48$ online simulation 5 (no remapping). The c 48 resolution allowed us to conduct a cubed-sphere off-line (GCHP) simulation, which we were not able to do at $\mathrm{c} 360$ resolution due to computational limitations.

Together, simulations 1-7 allow us to examine and isolate different sources of error in simulations of chemical transport including meteorological grid resolution, off-line meteorological archiving (temporal averaging), remapping of the meteorological archive, spatial degradation of that archive, and differences between off-line and online transport schemes. Salient results are discussed in the next section. We use monthly average zonal mean profiles vs. altitude and latitude as our comparison metric, following standard practice for ${ }^{222} \mathrm{Rn}$ model intercomparisons (Jacob et al., 1997). Another comparison metric for ${ }^{210} \mathrm{~Pb}$ and ${ }^{7} \mathrm{Be}$ is the global tropospheric lifetime against deposition (Liu et al., 2001). Throughout this paper, we refer to "archiving" as the temporal averaging of meteorological fields for use in off-line simulations, "remapping" as the cubed-sphere to rectilinear transformation of these fields, and "spatial averaging" as the further degradation of these fields from a fine to a coarse offline grid.

\section{Simulation results}

Figure 2a shows the zonal July mean profile of ${ }^{222} \mathrm{Rn}$ concentrations as a function of latitude and altitude from simulation 1. The latitudinal distribution reflects the continental source. The ${ }^{222} \mathrm{Rn}$ lifetime is much shorter than the vertical mixing time of the troposphere ( $\sim 1$ month), resulting in strong vertical gradients. The zonal mean concentration patterns are typical of those found in other models (Jacob et al., 1997).

\subsection{Errors from use of off-line convection scheme}

Figure $2 \mathrm{~b}$ shows the percentage differences in zonal mean ${ }^{222} \mathrm{Rn}$ profiles between simulation 2 (off-line GEOS-Chem convection scheme) and simulation 1 . Simulation 2 has up to $10 \%$ higher ${ }^{222} \mathrm{Rn}$ concentrations in the equatorial lower troposphere and up to $7 \%$ lower ${ }^{222} \mathrm{Rn}$ concentrations in the middle to upper troposphere. The combination of using the GEOS-Chem convection scheme and temporally averaged convective mass fluxes results in slightly reduced vertical transport compared to the original GEOS-5 convection.

The GEOS-Chem convection scheme operates as a single convective plume in each grid column on the basis of the $3 \mathrm{~h}$ archive of GEOS- 5 convective updraft and detrainment data. We find in a sensitivity simulation that using $15 \mathrm{~min}$ or $3 \mathrm{~h}$ averages of convective mass fluxes makes no significant difference. Thus the differences in Fig. 2 arise mainly from the bulk convective transport scheme used in GEOS-Chem, which simplifies the RAS ensemble-plume parameterization to a single plume. One explanation for why a multi-plume parameterization might produce a different transport pattern is that each sequential plume acts on a different concentration 

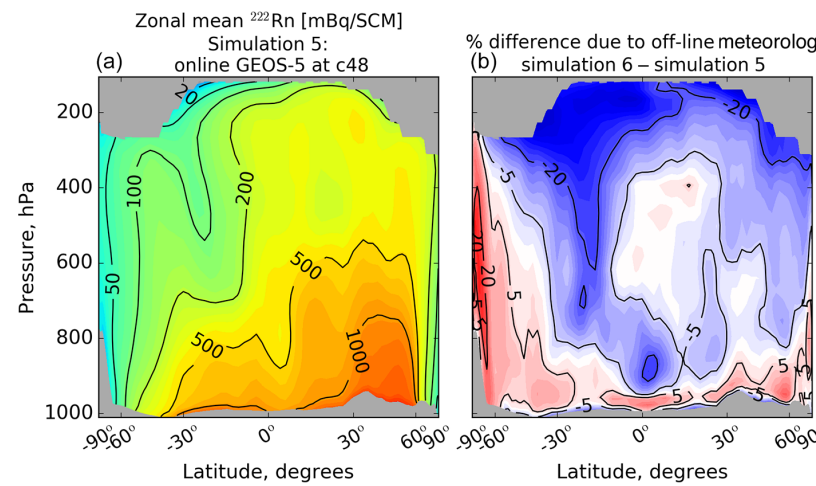

$\%$ difference due to rectilinear remapping and advection algorithm: (c) simulation 7 - simulation 6

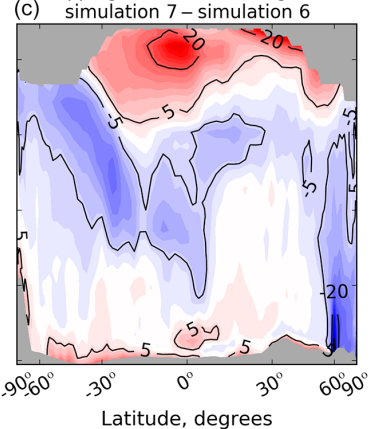

Figure 3. Off-line transport errors in ${ }^{222} \mathrm{Rn}$ concentrations simulated at $\mathrm{c} 48(\approx 200 \mathrm{~km})$ resolution. (a) Zonal monthly mean concentrations of ${ }^{222} \mathrm{Rn}$ for July 2013 from the online GEOS-5 simulation with c48 cubed-sphere resolution (simulation 5). (b) Errors due to off-line archiving of meteorological fields (no remapping) shown as percentage differences between simulation 6 and simulation 5. (c) Errors due to remapping of the meteorological archive from $\mathrm{c} 48$ to $2^{\circ} \times 2.5^{\circ}$ (rectilinear, $\approx 200 \mathrm{~km}$ ) and using a lower-order advection scheme shown as percentage differences between simulation 7 and simulation 6 .

gradient that has been modified by the previous plume until the moisture and temperature fields are balanced. A tall plume followed by a series of short plumes will transport more tracer higher than a series of shorter plumes followed by a tall plume.

\subsection{Errors from off-line vs. online simulation}

Figure $2 \mathrm{c}$ shows the percentage differences between simulation 3 (off-line) and simulation 2 (online). The off-line simulation has higher ${ }^{222} \mathrm{Rn}$ concentrations in the midtroposphere (700-500 hPa) and lower concentrations in the upper troposphere (above $500 \mathrm{hPa}$ ), with some differences exceeding $20 \%$. Encapsulated in this comparison are the effects of remapping the archived meteorological fields to a rectilinear grid using a different advection scheme, using a different boundary layer mixing scheme, and using $3 \mathrm{~h}$ averaged wind fields. Large relative differences in polar grid cells may reflect the averaging of concentrations in the polar latitudes in the rectilinear advection scheme (Lin and Rood, 1996) and the transition to semi-Lagrangian advection when the Courant number exceeds unity. ${ }^{222} \mathrm{Rn}$ concentrations are very low in these polar grid cells so that absolute differences are small.

To better understand the contributions from different sources of error in the off-line simulation, we examine simulations 5-7, which show a similar transition from online to off-line, but starting at c 48 resolution in the GEOS- 5 model and with the intermediate addition of a c48 off-line GCHP simulation (custom cubed-sphere archive, no remapping). In this way we can diagnose the effects of using archived meteorology separately from the effects of the advection core and remapping error associated with conversion to a rectilinear (here $2^{\circ} \times 2.5^{\circ}$ ) grid. Figure 3a shows the zonal mean ${ }^{222} \mathrm{Rn}$ concentrations for c48 resolution, which have a similar pattern to the c360 results. Figure $3 \mathrm{~b}$ and c additively separate out the contributions from off-line archiving (simulation 6 vs. simulation 5) and the remapping and transport scheme (simulation 7 vs. simulation 6). Off-line archiving results in overall weaker vertical transport, as might be expected from transient motions averaged out in the meteorological archive. The bias is about $5 \%$ in surface air but can exceed $20 \%$ in the upper troposphere. There is still a bias over Antarctica even though the off-line cubed-sphere geometry does not have a polar singularity; this may reflect the cumulative effect of meridional transport differences affecting a region particularly remote from sources. The combination of remapping to the rectilinear grid and using the Lin and Rood (1996) advection scheme (right panel) also incurs differences of about $5 \%$ in surface air and up to $20 \%$ in the upper troposphere. We would expect to see larger remapping errors associated with smaller grids, especially over the polar regions. The errors from simulations 6 and 7 compound for surface air but tend to cancel in the upper troposphere.

\subsection{Errors from grid resolution}

Figure 4 shows the effect of grid resolution on zonal mean ${ }^{222} \mathrm{Rn}$ profiles in GEOS-5 (online, with resolution affecting meteorology) and GEOS-Chem (off-line, using the same meteorological archive in both cases). Figure $4 \mathrm{~b}$ shows the percentage difference between simulation 5 (online c48) and simulation 2 (online c360). The c360 meteorological simulation has sufficient spatial resolution to resolve large convective systems and thus has much less parameterized convection than the $\mathrm{c} 48$ simulation. The higher ${ }^{222} \mathrm{Rn}$ concentrations in the tropical upper troposphere in $\mathrm{c} 48$ and lower concentrations in the extratropical upper troposphere most likely reflect differences in vertical transport properties between the resolved and parameterized convective formulations. Thus the higher concentrations in the tropical middle to upper troposphere at $\mathrm{c} 48$ can be attributed to the convec- 


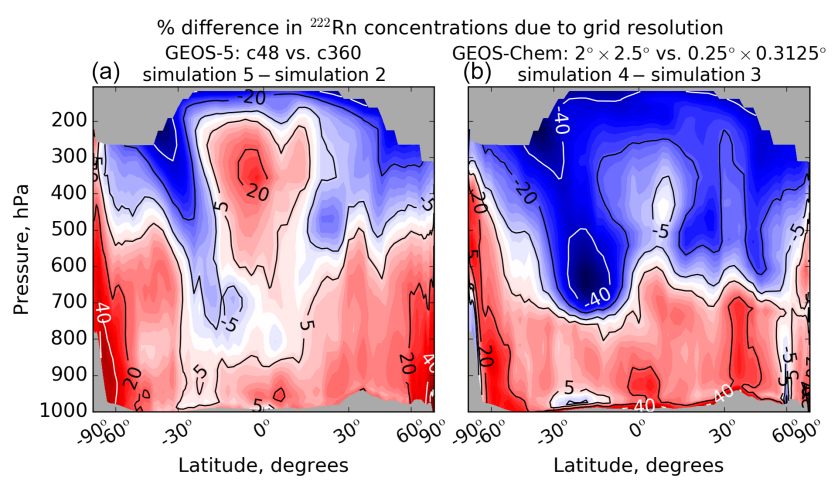

Figure 4. Effect of grid resolution on simulated zonal mean ${ }^{222} \mathrm{Rn}$ concentrations for July 2013. (a) Percentage differences between online GEOS-5 simulations at c48 resolution (simulation 5) and c360 resolution (simulation 2). (b) Percentage differences between off-line GEOS-Chem simulations at $2^{\circ} \times 2.5^{\circ}$ resolution (simulation 4 ) and $0.25^{\circ} \times 0.3125^{\circ}$ resolution (simulation 3 ).

tive fluxes that are not represented by the resolved transport at $\mathrm{c} 360$. The lower concentrations near the tropopause can be attributed to the known insufficiency of convective transport for reaching that level (Ott et al., 2009). The lower concentrations in the extratropical upper troposphere may be due to inability to diagnose organized vertical motion as convection. The higher concentrations over Antarctica at c48 may be due to numerical diffusion during the slow long-range meridional transport from lower latitudes (Eastham and Jacob, 2017). While these differences are large, absolute concentrations are very low over the poles due to the short lifetime of ${ }^{222} \mathrm{Rn}$ and lack of emission over ice and snow.

Degrading model resolution has different effects in GEOSChem, in which the coarse $2^{\circ} \times 2.5^{\circ}$ simulation uses the same $0.25^{\circ} \times 0.3125^{\circ}$ meteorological archive as the highresolution simulation but with spatial averaging of the meteorological fields. The coarse simulation results in decreased vertical transport to the upper troposphere at all latitudes, with maximum effect (up to $40 \%$ ) in the subsiding subtropics. This may be simply explained by the averaging out of vertical eddy motions on the coarser grid, including organized vertical motions across multiple levels that the online c48 simulation would simulate with stronger parameterized convection. This systematic bias in the coarse-resolution GEOS-Chem may thus be correctable through the addition of convective motions. We explore this idea in the next section.

\subsection{Errors from grid resolution for ${ }^{210} \mathrm{~Pb}$ and ${ }^{7} \mathrm{Be}$}

Figure 5 (top panels) shows the zonal mean concentrations of ${ }^{210} \mathrm{~Pb}$ and ${ }^{7} \mathrm{Be}$ from the GEOS-Chem simulation at $0.25^{\circ} \times 0.3125^{\circ}$ (simulation 3). The ${ }^{210} \mathrm{~Pb}$ distribution is shifted to higher altitudes relative to ${ }^{222} \mathrm{Rn}$, reflecting the effect of scavenging in the lower troposphere. ${ }^{7} \mathrm{Be}$ shows preferential subsidence in the dry subtropics and is depleted in
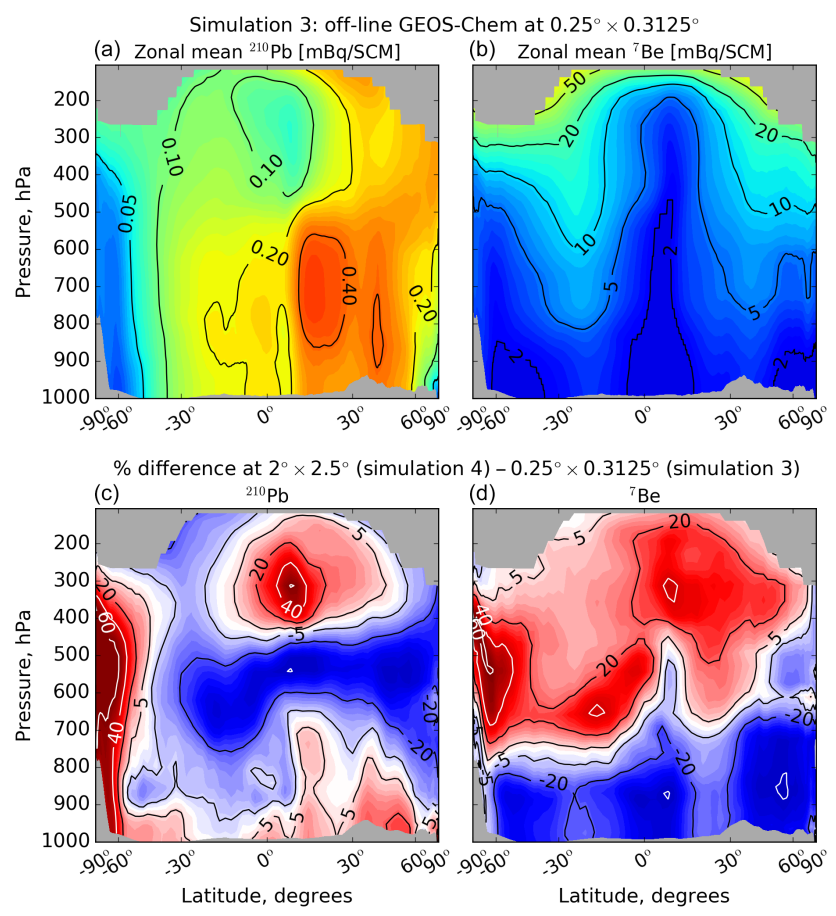

Figure 5. Simulated GEOS-Chem zonal mean concentrations of ${ }^{210} \mathrm{~Pb}$ and ${ }^{7} \mathrm{Be}$ at $0.25^{\circ} \times 0.3125^{\circ}$ grid resolution (simulation 3; a, b) and the effect of degrading grid resolution to $2^{\circ} \times 2.5^{\circ}$ (simulation 4; c, d). Concentrations are monthly means for July 2013 after a 1-month spin-up from zero concentrations and are expressed in mixing ratio units of millibecquerels per standard cubic meter (at $0^{\circ} \mathrm{C}$ and $1 \mathrm{~atm}$ pressure) or $\mathrm{mBq} \mathrm{SCM}^{-1}$. (c, d) Percentage differences between simulation 4 and simulation 3 .

the lower troposphere by scavenging. ${ }^{7} \mathrm{Be}$ concentrations are low throughout the tropical troposphere due to dominant upwelling of ${ }^{7} \mathrm{Be}$-depleted surface air.

Mean tropospheric lifetimes against deposition in the $0.25^{\circ} \times 0.3125^{\circ}$ simulation are 6.7 days for ${ }^{210} \mathrm{~Pb}$ and 17 days for ${ }^{7} \mathrm{Be}$. Liu et al. (2001) previously inferred ${ }^{210} \mathrm{~Pb}$ and ${ }^{7} \mathrm{Be}$ tropospheric residence times of 9 and 21 days, respectively, from an earlier version of GEOS-Chem evaluated with observations. A more recent evaluation by Zhang et al. (2017) using GEOS-Chem version 11-01 and an updated ${ }^{222} \mathrm{Rn}$ source finds that a residence time for ${ }^{210} \mathrm{~Pb}$ of $7 \pm 1$ days better matches the observational constraints.

The bottom panels show the effects of degrading the GEOS-Chem resolution to $2^{\circ} \times 2.5^{\circ}$. Overall the results are consistent with our previous finding for ${ }^{222} \mathrm{Rn}$ that degrading the resolution weakens vertical transport. Tropospheric lifetimes decrease to 6.2 days for ${ }^{210} \mathrm{~Pb}$ and increase to 18 days for ${ }^{7} \mathrm{Be}$, with is consistent with the shifts in vertical distribution to the lower troposphere for ${ }^{210} \mathrm{~Pb}$ and to the upper troposphere for ${ }^{7} \mathrm{Be} .{ }^{210} \mathrm{~Pb}$ concentrations are higher in the tropical upper troposphere in the $2^{\circ} \times 2.5^{\circ}$ simulation, likely due to differences in wet scavenging. 


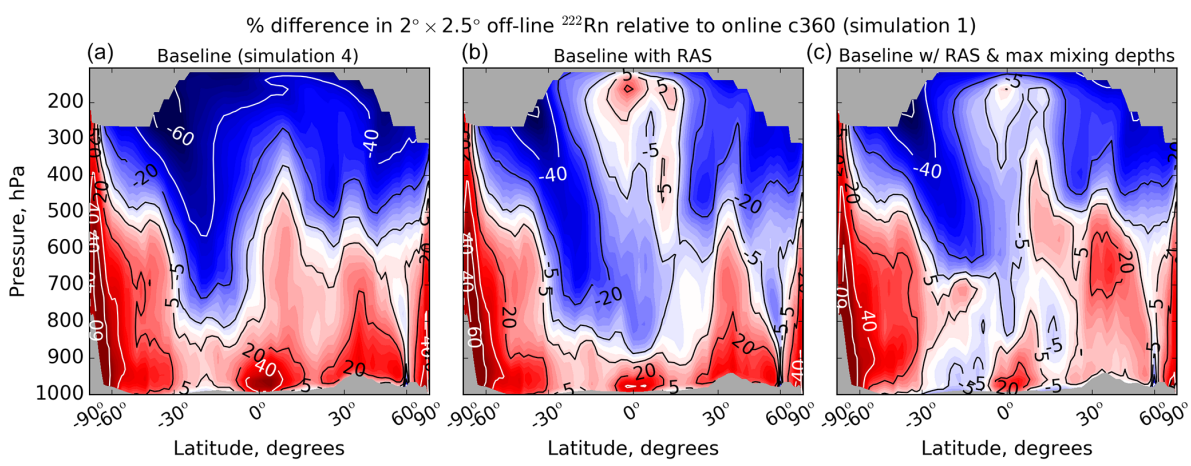

Figure 6. Errors in off-line coarse-resolution $\left(2^{\circ} \times 2.5^{\circ}\right)$ simulations of ${ }^{222} \mathrm{Rn}$ concentrations relative to the reference online c360 GEOS-5 simulation (simulation 1). Values are percentage differences in zonal mean concentrations for July 2013. (a) Errors for the baseline $2^{\circ} \times 2.5^{\circ}$ GEOS-Chem simulation. (b) Errors for the same baseline but with adjusted RAS convective mass fluxes (see text). (c) Errors for the same baseline with adjusted RAS convective mass fluxes and maximum mixing depths for each coarse-resolution grid cell (cf. Fig. 9).

(a) ${ }^{222} \mathrm{Rn}$ at $900 \mathrm{hPa}$ (simulation 1, c360)

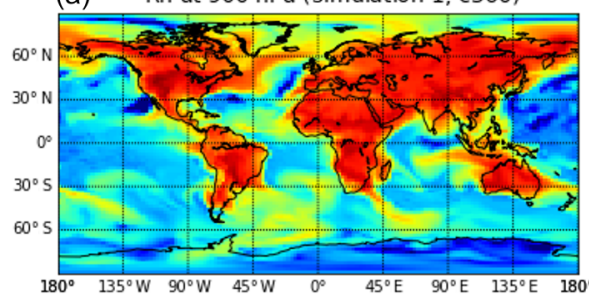

(b) ${ }^{222} \mathrm{Rn}$ at $900 \mathrm{hPa}$ (simulation $4,2^{\circ} \times 2.5^{\circ}$ )

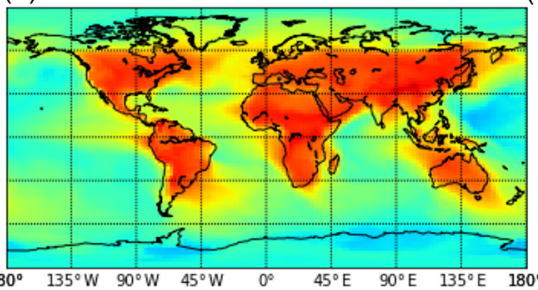

(c) \% difference in ${ }^{222} \mathrm{Rn}\left(2^{\circ} \times 2.5^{\circ}-\mathrm{c} 360\right)$ at $900 \mathrm{hPa}$

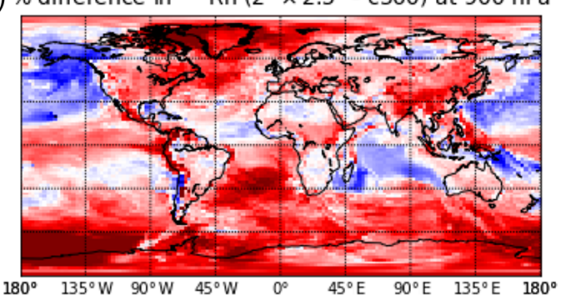

(d) ${ }^{222} \mathrm{Rn}$ at $500 \mathrm{hPa}$ (simulation $1, \mathrm{c360}$ )

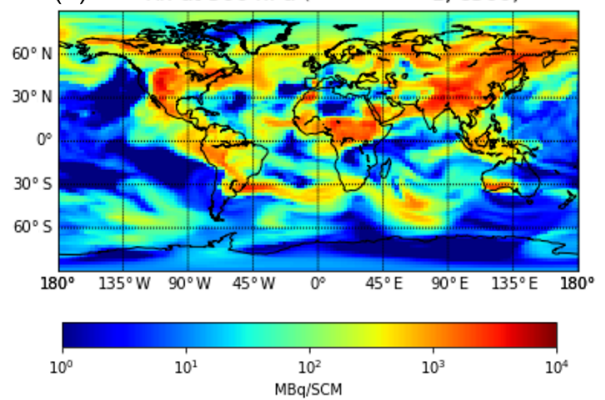

(e) ${ }^{222} \mathrm{Rn}$ at $500 \mathrm{hPa}$ (simulation $4,2^{\circ} \times 2.5^{\circ}$ )

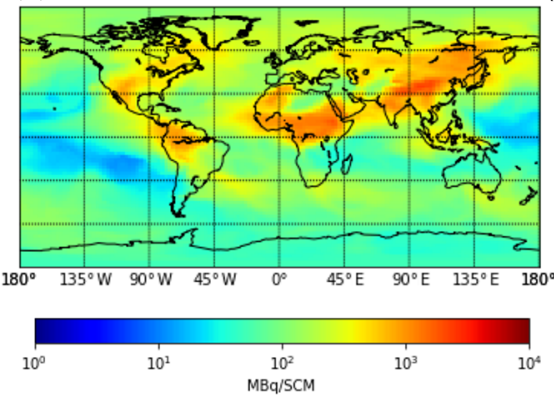

(f) $\%$ difference in ${ }^{222} \mathrm{Rn}\left(2^{\circ} \times 2.5^{\circ}-\mathrm{c} 360\right)$ at $500 \mathrm{hPa}$

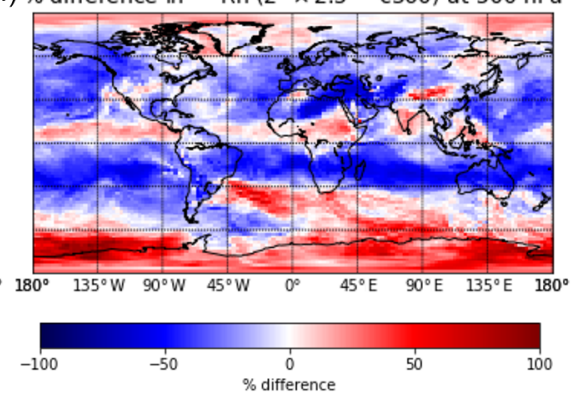

Figure 7. ${ }^{222} \mathrm{Rn}$ concentrations at $900 \mathrm{hPa}(\mathbf{a}-\mathbf{c})$ and $500 \mathrm{hPa}(\mathbf{d}-\mathbf{f})$ from the reference online c360 GEOS-5 simulation (simulation 1 ; a, d) and off-line $2^{\circ} \times 2.5^{\circ}$ GEOS-Chem simulation (simulation $\left.4 ; \mathbf{b}, \mathbf{e}\right)$. (c, f) The percent difference in ${ }^{222} \mathrm{Rn}$ concentrations in simulation 4 relative to simulation 1 .

\section{Correcting errors in off-line simulations}

Our work has shown how a cascade of errors is introduced in the model transport of chemical tracers when using off-line meteorological archives (as opposed to online simulation) and when degrading the spatial resolution of these archives for computational expediency. The compounding effect is illustrated in Fig. 6a, which compares the zonal mean ${ }^{222} \mathrm{Rn}$ concentration profiles in the off-line $2^{\circ} \times 2.5^{\circ}$ configuration of GEOS-Chem to the online GEOS-5 simulation at c360 $(\approx 25 \mathrm{~km})$ resolution. Concentrations are typically biased high by $\sim 20 \%$ at the surface and biased low by $\sim 40 \%$ in the upper troposphere. Figure 7 shows the same compari- son as Fig. 6a but for concentrations at 900 and $500 \mathrm{hPa}$. We see that the c360 simulation is better able to capture the filamentary structure of outflow from continental source regions, while these patterns are not apparent in the $2^{\circ} \times 2.5^{\circ}$ simulation. Concentrations are higher overall for the $2^{\circ} \times 2.5^{\circ}$ simulation at $900 \mathrm{hPa}$ and lower at $500 \mathrm{hPa}$, which is consistent with the vertical profiles. At $500 \mathrm{hPa}$, the fine structure of transport is even more apparent in the high-resolution simulation. We now examine how some of these errors can be alleviated.

We can categorize the errors as resulting from four different sources: (1) differences in transport algorithms between the off-line and online model (advection scheme, boundary 

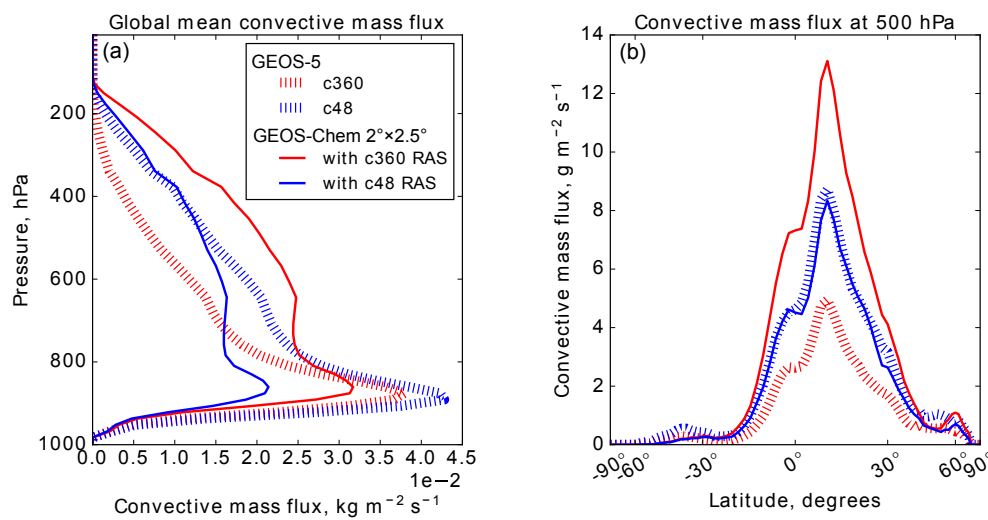

Figure 8. Convective mass fluxes for July 2013 produced by the GEOS-5 GCM at cubed-sphere $\mathrm{c} 360(\approx 25 \mathrm{~km})$ and $\mathrm{c} 48(\approx 200 \mathrm{~km})$ resolution using the Relaxed Arakawa-Schubert (RAS) scheme and by the $2^{\circ} \times 2.5^{\circ}(\approx 200 \mathrm{~km})$ GEOS-Chem simulation using the RAS scheme with c360 and c48 GEOS-5 meteorology. (a) Vertical profile of global mean convective mass flux. (b) Zonal mean convective mass flux at $500 \mathrm{hPa}$ as a function of latitude.

layer mixing, convective parameterization); (2) remapping of the meteorological archive (as here from a cubed-sphere to a rectilinear grid); (3) temporal averaging in the meteorological archive (causing loss of eddy motions, including gridresolved organized convection, and requiring a pressure fixer to correct horizontal winds); and (4) spatial degradation of the meteorological archive (causing further loss of eddy motions). Our work presented in Sect. 4 shows that all of these general sources of error are important, and addressing some of them requires improvement of the off-line archive. For example, an obvious improvement in our case would be for the GEOS-5 meteorological archive to be available on the native cubed-sphere grid rather than remapped to a rectilinear grid. Increasing the temporal frequency of archiving would be another obvious improvement.

Here we examine the feasibility of restoring the organized vertical motions lost in the temporal averaging of the meteorological archive or in the spatial averaging for coarse-resolution GEOS-Chem simulations. Charlton-Perez et al. (2009) previously found that vertical motions in a large-eddy simulation at $200-200 \mathrm{~m}$ resolution could be preserved at coarser resolution by an eddy accumulation method in which upward and downward vertical winds are averaged separately. We implemented this method by taking the archived pressure velocity $(\omega)$ as $3 \mathrm{~h}$ averages from the native $0.25^{\circ} \times 0.3125^{\circ}$ meteorological archive and separately averaging the upwards and downwards values onto the coarseresolution $2^{\circ} \times 2.5^{\circ}$ grid. We then compared these values to the value computed by GEOS-Chem on the $2^{\circ} \times 2.5^{\circ}$ grid, took the difference as the component of vertical advection lost due to spatial degradation, and applied this difference as a vertical mass exchange velocity (i.e., eddy diffusion) between adjacent cells. We found that this made negligible change to the ${ }^{222} \mathrm{Rn}$ simulation, implying that the transport error on our scales is due more to loss of organized convective motion than to loss of small-scale eddies.
Figure 8 shows the mean July 2013 convective mass fluxes from the c360 and c48 GEOS-5 simulations globally as vertical profiles (panel a) and at $500 \mathrm{hPa}$ as a function of latitude (panel b). Convective mass fluxes are highest just above cloud base in the lower troposphere and highest in the northern tropics (ITCZ). The global convective mass flux is $24 \%$ weaker in the $\mathrm{c} 360$ than in the $\mathrm{c} 48$ simulation. In the $\mathrm{c} 360$ simulation, parameterized convection is less needed because the organized convective motions are partly resolved. Similar to the eddy motions, much of this resolved convective motion is lost when winds produced by a high-resolution GCM are first temporally averaged in a $3 \mathrm{~h}$ archive and then spatially averaged to a coarse grid.

A possible way to compensate for this lost convective motion in the meteorological archive is to increase parameterized convection in the off-line CTM. A simple approach would be to increase the archived convective mass fluxes by an adjustable factor, but this assumes that the archived fluxes are colocated with the lost convection. A more physical approach is to recompute the convective mass fluxes on the fly in the off-line CTM simulation by using the same convective parameterization (here RAS) as in the parent GCM and applied to the meteorological archive with the scale-aware settings configured for the CTM resolution. This approach incurs little additional computational cost because computations associated with the hydrological cycle in RAS are not performed. It may still underestimate the GCM convection because the archived meteorological fields used by the CTM are convectively relaxed temporal averages, but this can be corrected by adjusting the convective parameterization settings.

We implemented the GEOS-5 RAS scheme within GEOSChem in lieu of the archived convective mass fluxes, taking as input water vapor, temperature, mixing depth, and surface pressure fields from the archived meteorological data. The RAS scheme outputs the convective air mass flux and 
detrainment flux at every dynamic time step. We then used these fluxes to drive convective transport in GEOS-Chem, retaining the GEOS-Chem convective algorithm for consistent treatment of scavenging. Off-line $2^{\circ} \times 2.5^{\circ}$ GEOSChem simulations were conducted in this manner using both c360 and c48 meteorological fields.

Figure 8 shows the resulting global mean convective mass fluxes produced by GEOS-Chem at $2^{\circ} \times 2.5^{\circ}$ resolution using RAS to compute the convective mass flux based on archived meteorological data from the c360 and c48 meteorological archives. The vertical and latitudinal distributions closely match those computed in GEOS-5 (simulations 1 and 5, respectively). With c360 meteorology, the RAS-computed convective mass fluxes in GEOS-Chem are $30 \%$ higher globally than in GEOS-5 at that resolution (solid and dashed red lines), responding as desired to the scaleaware settings corresponding to the coarser resolution of the CTM. With c48 meteorology, the RAS-computed convective mass fluxes in GEOS-Chem are $35 \%$ weaker globally than in GEOS-5 (solid and dashed blue lines); here the CTM has the same spatial resolution as the GCM, and the weaker convection is expected from temporal averaging of the meteorological archive as discussed above. The larger difference between GEOS-5 and GEOS-Chem convective mass fluxes below $500 \mathrm{hPa}$ compared to above $500 \mathrm{hPa}$ suggests that convective motions penetrating higher altitudes are more likely to be retained after temporal averaging.

We can increase convection produced by RAS by applying a temperature perturbation at the surface. On the scale of global CTMs (hundreds of kilometers), there is substantial sub-grid variability in moisture and temperature, with convection occurring preferentially over the more buoyant parts of the grid cell. Using moisture and temperature fields averaged over these large grid cells and over time will result in RAS underestimating convection. Therefore, we add a temperature perturbation proportional to the vertical temperature gradient at the surface (applied only when surface temperature is greater than air temperature) to generate increased thermodynamic instability, an approach that is also used in the GEOS-5 GCM operating at coarse resolutions. We set a limit of $3.0 \mathrm{~K}$ as the maximum allowable temperature perturbation. This leads to convective mass fluxes that are 2.5 times as much as the archived values.

Figure $6 \mathrm{~b}$ shows the effect of including RAS in GEOSChem at $2^{\circ} \times 2.5^{\circ}$ resolution using c360 meteorology. There is substantial improvement in the tropics relative to the standard GEOS-Chem simulation using archived convective mass fluxes (panel a). Extratropical regions show less improvement, as vertical transport is driven more by baroclinic instability rather than convection.

We further investigated whether spatial averaging of boundary layer mixing depths from the high-resolution meteorological archive could weaken vertical transport in coarseresolution off-line simulations. As shown by the diagram in Fig. 9, spatial averaging of mixing depths prevents boundary

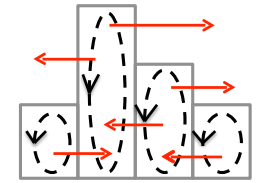

(a) High resolution

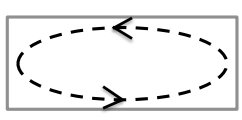

(b) Coarse resolution with average mixing depth

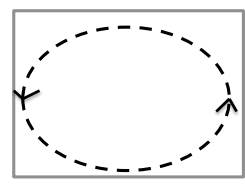
maximum mixing depth (c) Coarse resolution with

Figure 9. Effect of averaging high-resolution mixing depths in coarse-resolution simulations. (a) Mixing at high grid resolution; the vertical extents of the boxes denote mixing depths and the dashed arrows illustrate the mixing. Red arrows show the induced circulation for a chemical tracer emitted at the surface. (b, c) Mixing at coarse resolution with mixing depth taken as the average or the maximum of the high-resolution values.

layer mixing to higher altitudes that would otherwise take place in part of the domain. This mixing would then drive a circulation ventilating a larger fraction of the domain to higher altitudes than specified by the average mixing depth. To assess the potential magnitude of this effect, we conducted a sensitivity simulation using the maximum $0.25^{\circ} \times 0.3125^{\circ}$ mixing depth within a $2^{\circ} \times 2.5^{\circ}$ grid cell as the mixing depth for that grid cell. These mixing depths are used in place of the mean mixing depths in boundary layer mixing and in RAS. The result is shown in Fig. 6c. The simulation of surface concentrations is improved although there is overcompensation in the middle troposphere.

\section{Conclusions}

In this work, we isolated the different sources of transport errors resulting from performing off-line chemical transport model (CTM) simulations with archived meteorological data from a general circulation model (GCM). Errors include temporal averaging and remapping of the meteorological archive, differences in transport algorithms (sometimes required by lack of information in the archive), and coarsening of the CTM grid to enable simulations with a large number of chemically coupled species. We then explored some possibilities for reducing these errors.

We used as a reference an online simulation of the ${ }^{222} \mathrm{Rn}-{ }^{210} \mathrm{~Pb}-{ }^{7} \mathrm{Be}$ chemical tracer suite in the Goddard Earth Observing System (GEOS-5) GCM at cubed-sphere $\mathrm{c} 360(\approx 25 \mathrm{~km})$ resolution. The operational meteorological archive from GEOS-5, stored as $3 \mathrm{~h}$ averages ( $1 \mathrm{~h}$ for mixing depths $)$ and remapped onto a $0.25^{\circ} \times 0.3125^{\circ}(\approx 25 \mathrm{~km})$ rectilinear grid, provides the standard input to the GEOS-Chem CTM used by a large research community for atmospheric chemistry applications. These applications often degrade the meteorological archive to $2^{\circ} \times 2.5^{\circ}(\approx 200 \mathrm{~km})$ horizontal resolution (coarse-resolution GEOS-Chem) to make global chemical simulations computationally tractable. We conducted an ensemble of simulations to document the cascade of errors involved in going from the online GEOS-5 high- 
resolution simulation to the off-line GEOS-Chem coarseresolution simulation. Although our study focuses on a particular GCM-CTM combination, our findings have relevance for any CTM driven by meteorology produced at high resolution. Vertical transport errors are of particular interest and the ${ }^{222} \mathrm{Rn}-{ }^{210} \mathrm{~Pb}-{ }^{7} \mathrm{Be}$ tracer suite is well suited for that purpose. We first diagnosed the cascade of transport errors in the ${ }^{222} \mathrm{Rn}$ simulation when going from the online c360 GEOS5 simulation to the off-line $0.25^{\circ} \times 0.3125^{\circ}$ GEOS-Chem simulation. The error from using temporally averaged convective mass fluxes is relatively small. The errors from using archived winds and from remapping c360 fields to $0.25^{\circ} \times 0.3125^{\circ}$ are both more severe, resulting together in 5-20\% biases. Transport from the boundary layer to the upper troposphere is too weak in the off-line model and this is due at least in part to loss of transient organized advective motions (resolved convection) in the $3 \mathrm{~h}$ averaging of the meteorological archive.

We then examined the effect of degrading the spatial resolution of the meteorological archive from $0.25^{\circ} \times 0.3125^{\circ}$ to $2^{\circ} \times 2.5^{\circ}$ for input to the coarse-resolution GEOS-Chem. This further weakened vertical transport by up to $40 \%$ as organized vertical motions in the $0.25^{\circ} \times 0.3125^{\circ}$ archive were averaged out in the $2^{\circ} \times 2.5^{\circ}$ archive. The weakened vertical transport also affected the lifetimes of ${ }^{210} \mathrm{~Pb}$ and ${ }^{7} \mathrm{Be}$ by 5-10\% against deposition.

We explored different possibilities for restoring vertical transport in the off-line coarse-resolution simulation. Archiving eddy vertical winds between adjacent vertical layers was found to be of negligible benefit, indicating that the loss of nonlocal organized vertical motions is more important. The spatial averaging of boundary layer mixing depths leads to underestimates of vertical transport, and this can be corrected by weighting the averaging towards higher values. We showed that the loss of vertical organized convective motions could be corrected to some extent by using the online GCM convection scheme (here the Relaxed Arakawa-Schubert or RAS) to operate at the coarse resolution of the CTM using the meteorological archive as input. This improves vertical transport in the tropics but has little effect at higher latitudes.

Our work has revealed significant vertical transport errors in off-line CTM applications when using meteorological archives from a GCM operating at high resolution. Given these large differences in vertical transport, users examining the effect of convection on a chemical species should take care to perform their simulations at sufficiently high resolution. Those conducting simulations of long-lived trace gases such as $\mathrm{CO}_{2}$ or $\mathrm{CH}_{4}$ should also be aware of these errors.

As the resolution of the GCMs continues to increase, the amount of transport information lost in off-line CTMs will also increase. This may be corrected, in order of priority, by (1) applying scale-dependent convective transport parameterizations off-line, (2) avoiding remapping of the archive by archiving on the cubed-sphere grid, (3) using consistent transport algorithms (in the case of GEOS-Chem, Put- man and Lin, 2010, rather than Lin and Rood, 1996), and (4) increasing the frequency of archiving. Of the list, (1) will only require a minor increase in computational time, (2) and (4) will increase both data storage and computational resources, and (3) will require no additional resources if (2) is done. These improvements will benefit off-line simulations at all resolutions, including high-resolution nested simulations. We plan to include these improvements in future versions of the standard GEOS-Chem code.

Code availability. The GEOS-Chem source code is freely available to the public. Source code may be downloaded by following the instructions found at http://wiki.geos-chem.org/. At the time of writing, this work used a modified version of GEOS-Chem version 1101 (the most recent public release) as indicated in the text. All developments presented here will be included in the next public release (version 11-02) of GEOS-Chem (http://wiki.seas.harvard.edu/ geos-chem/index.php/GEOS-Chem_v11-02). If you wish to access the code used in this work prior to the public release of version 1102, you may do so at https://github.com/kyu0110/geoschem_ras.

Competing interests. The authors declare that they have no conflict of interest.

Acknowledgements. This work was funded by the Modeling, Analysis, and Prediction (MAP) program of the NASA Earth Science Division.

Edited by: Fiona O'Connor

Reviewed by: two anonymous referees

\section{References}

Allen, D. J., Rood, R. B., Thompson, A. M., and Hudson, R. D.: Three-dimensional radon 222 calculations using assimilated meteorological data and a convective mixing algorithm, J. Geophys. Res., 101, 6871-6881, 1996.

Bacmeister, J. T. and Stephens, G.: Spatial statistics of likely convective clouds in CloudSat data, J. Geophys. Res.-Atmos., 116, D04104, https://doi.org/10.1029/2010JD014444, 2011.

Bacmeister, J. T., Suarez, M. J., and Robertson, F. R.: Rain reevaporation, boundary layer-convection interactions, and Pacific rainfall patterns in an AGCM, J. Atmos. Sci., 63, 3383-3403, 2006.

Balkanski, Y. J., Jacob, D. J., Gardner, G. M., Graustein, W. C., and Turekian, K. K.: Transport and residence times of tropospheric aerosols inferred from a global three-dimensional simulation of ${ }^{210} \mathrm{~Pb}$, J. Geophys. Res.-Atmos., 98, 20573-20586, 1993.

Bey, I., Jacob, D. J., Yantosca, R. M., Logan, J. A., Field, B. D., Fiore, A. M., Li, Q., Liu, H. Y., Mickley, L. J., and Schultz, M. G.: Global modeling of tropospheric chemistry with assimilated meteorology: Model description and evaluation, J. Geophys. Res.-Atmos., 106, 23073-23095, 2001.

Brasseur, G. P. and Jacob, D. J.: Modeling of Atmospheric Chemistry, Cambridge University Press, Cambridge, 2017. 
Charlton-Perez, C. L., Evans, M. J., Marsham, J. H., and Esler, J. G.: The impact of resolution on ship plume simulations with $\mathrm{NO}_{x}$ chemistry, Atmos. Chem. Phys., 9, 7505-7518, https://doi.org/10.5194/acp-9-7505-2009, 2009.

Chen, D., Wang, Y., McElroy, M. B., He, K., Yantosca, R. M., and Le Sager, P.: Regional CO pollution and export in China simulated by the high-resolution nested-grid GEOS-Chem model, Atmos. Chem. Phys., 9, 3825-3839, https://doi.org/10.5194/acp-93825-2009, 2009.

Colarco, P., da Silva, A., Chin, M., and Diehl, T.: Online simulations of global aerosol distributions in the NASA GEOS-4 model and comparisons to satellite and ground-based aerosol optical depth, J. Geophys. Res.-Atmos., 115, D14207, https://doi.org/10.1029/2009JD012820, 2010.

Considine, D. B., Bergmann, D. J., and Liu, H.: Sensitivity of Global Modeling Initiative chemistry and transport model simulations of radon-222 and lead-210 to input meteorological data, Atmos. Chem. Phys., 5, 3389-3406, https://doi.org/10.5194/acp5-3389-2005, 2005.

Dentener, F., Feichter, J., and Jeuken, A.: Simulation of the transport of Rn222 using on-line and off-line global models at different horizontal resolutions: a detailed comparison with measurements, Tellus B, 51, 573-602, 1999.

Donner, L. J., Wyman, B. L., Hemler, R. S., Horowitz, L. W., Ming, Y., Zhao, M., Golaz, J.-C., Ginoux, P., Lin, S.-J., Schwarzkopf, M. D., Austin, J., Alaka, G., Cooke, W. F., Delworth, T. L., Freidenreich, S. M., Gordon, C. T., Griffies, S. M., Held, I. M., Hurlin, W. J., Klein, S. A., Knutson, T. R., Langenhorst, A. R., Lee, H., Lin, Y., Magi, B. I., Malyshev, S. L., Milly, P. C., Naik, V., Nath, M. J., Pincus, R., Ploshay, J. J., Ramaswamy, V., Seman, C. J., Shevliakova, E., Sirutis, J. J., Stern, W. F., Stouffer, R. J., Wilson, R. J., Winton, M., Wittenberg, A. T., and Zeng, F.: The dynamical core, physical parameterizations, and basic simulation characteristics of the atmospheric component AM3 of the GFDL global coupled model CM3, J. Climate, 24, 3484-3519, 2011.

Douglass, A. R., Prather, M., Hall, T., Strahan, S., Rasch, P., Sparling, L., Coy, L., and Rodriguez, J.: Choosing meteorological input for the global modeling initiative assessment of high-speed aircraft, J. Geophys. Res.-Atmos., 104, 27545-27564, 1999.

Douglass, A. R., Stolarski, R. S., Strahan, S. E., and Connell, P. S.: Radicals and reservoirs in the GMI chemistry and transport model: Comparison to measurements, J. Geophys. Res.-Atmos., 109, D16302, https://doi.org/10.1029/2004JD004632, 2004.

Eastham, S. D. and Jacob, D. J.: Limits on the ability of global Eulerian models to resolve intercontinental transport of chemical plumes, Atmos. Chem. Phys., 17, 2543-2553, https://doi.org/10.5194/acp-17-2543-2017, 2017.

Emmons, L. K., Walters, S., Hess, P. G., Lamarque, J.-F., Pfister, G. G., Fillmore, D., Granier, C., Guenther, A., Kinnison, D., Laepple, T., Orlando, J., Tie, X., Tyndall, G., Wiedinmyer, C., Baughcum, S. L., and Kloster, S.: Description and evaluation of the Model for Ozone and Related chemical Tracers, version 4 (MOZART-4), Geosci. Model Dev., 3, 43-67, https://doi.org/10.5194/gmd-3-43-2010, 2010.

Feng, W., Chipperfield, M. P., Dhomse, S., Monge-Sanz, B. M., Yang, X., Zhang, K., and Ramonet, M.: Evaluation of cloud convection and tracer transport in a three-dimensional chem- ical transport model, Atmos. Chem. Phys., 11, 5783-5803, https://doi.org/10.5194/acp-11-5783-2011, 2011.

Gelaro, R., McCarty, W., Suárez, M. J., Todling, R., Molod, A., Takacs, L., Randles, C., Darmenov, A., Bosilovich, M. G., Reichle, R., Wargan, K., Coy, L., Cullather, R., Draper, C., Akella, S., Buchard, V., Conaty, A., da Silva, A. M., Gu, W., Kim, G., Koster, R., Lucchesi, R., Merkova, D., Nielsen, J. E., Partyka, G., Pawson, S., Putman, W., Rienecker, M., Schubert, S. D., Sienkiewicz, M., and Zhao, B.: The Modern-Era Retrospective Analysis for Research and Applications, Version 2 (MERRA-2), J. Climate, 30, 5419-5454, https://doi.org/10.1175/JCLI-D-160758.1, 2017.

Giorgi, F. and Chameides, W. L.: Rainout lifetimes of highly soluble aerosols and gases as inferred from simulations with a general circulation model, J. Geophys. Res.-Atmos., 91, 14367-14376, https://doi.org/10.1029/JD091iD13p14367, 1986.

Grell, G. A. and Freitas, S. R.: A scale and aerosol aware stochastic convective parameterization for weather and air quality modeling, Atmos. Chem. Phys., 14, 5233-5250, https://doi.org/10.5194/acp-14-5233-2014, 2014.

Grell, G. A., Knoche, R., Peckham, S. E., and McKeen, S. A.: Online versus offline air quality modeling on cloud-resolving scales, Geophys. Res. Lett., 31, L16117, https://doi.org/10.1029/2004GL020175, 2004.

Holtslag, A. and Boville, B.: Local versus nonlocal boundary-layer diffusion in a global climate model, J. Climate, 6, 1825-1842, 1993.

Horowitz, L. W., Walters, S., Mauzerall, D. L., Emmons, L. K., Rasch, P. J., Granier, C., Tie, X., Lamarque, J.-F., Schultz, M. G., Tyndall, G. S., Orlando, J. J., and Brasseur, G. P.: A global simulation of tropospheric ozone and related tracers: Description and evaluation of MOZART, version 2, J. Geophy. Res.-Atmos., 108, 4784, https://doi.org/10.1029/2002JD002853, 2003.

Jacob, D. J. and Prather, M. J.: Radon-222 as a test of convective transport in a general circulation model, Tellus B, 42, 118-134, 1990.

Jacob, D. J., Prather, M. J., Rasch, P. J., Shia, R.-L., Balkanski, Y. J., Beagley, S. R., Bergmann, D. J., Blackshear, W., Brown, M., Chiba, M., Chipperfield, M. P., de Grandpré, J., Dignon, J. E., Feichter, J., Genthon, C., Grose, W. L., Kasibhatla, P. S., Köhler, I., Kritz, M. A., Law, K., Penner, J. E., Ramonet, M., Reeves, C. E., Rotman, D. A., Stockwell, D. Z., Van Velthoven, P. F. J., Verver, G., Wild, O., Yang, H., and Zimmermann, P.: Evaluation and intercomparison of global atmospheric transport models using ${ }^{222} \mathrm{Rn}$ and other short-lived tracers, J. Geophys. Res.-Atmos. 102, 5953-5970, 1997.

Kim, P. S., Jacob, D. J., Fisher, J. A., Travis, K., Yu, K., Zhu, L., Yantosca, R. M., Sulprizio, M. P., Jimenez, J. L., CampuzanoJost, P., Froyd, K. D., Liao, J., Hair, J. W., Fenn, M. A., Butler, C. F., Wagner, N. L., Gordon, T. D., Welti, A., Wennberg, P. O., Crounse, J. D., St. Clair, J. M., Teng, A. P., Millet, D. B., Schwarz, J. P., Markovic, M. Z., and Perring, A. E.: Sources, seasonality, and trends of southeast US aerosol: an integrated analysis of surface, aircraft, and satellite observations with the GEOS-Chem chemical transport model, Atmos. Chem. Phys., 15, 10411-10433, https://doi.org/10.5194/acp-15-104112015, 2015.

Koch, D. M., Jacob, D. J., and Graustein, W. C.: Vertical transport of tropospheric aerosols as indicated by ${ }^{7} \mathrm{Be}$ and ${ }^{210} \mathrm{~Pb}$ in 
a chemical tracer model, J. Geophys. Res., 101, 18651-18666, https://doi.org/10.1029/96JD01176, 1996.

Kouatchou, J., Molod, A., Nielsen, J., Auer, B., Putman, W., and Clune, T.: GEOS-5 Chemistry Transport Model User's Guide, NASA Technical Report, NASA Goddard Space Flight Center, Greenbelt, Maryland, 2015.

Lal, D. and Peters, B.: Cosmic ray produced radioactivity on the earth, in: Kosmische Strahlung II/Cosmic Rays II, Springer, 551612, 1967.

Lamarque, J.-F., Emmons, L. K., Hess, P. G., Kinnison, D. E., Tilmes, S., Vitt, F., Heald, C. L., Holland, E. A., Lauritzen, P. H., Neu, J., Orlando, J. J., Rasch, P. J., and Tyndall, G. K.: CAM-chem: description and evaluation of interactive atmospheric chemistry in the Community Earth System Model, Geosci. Model Dev., 5, 369-411, https://doi.org/10.5194/gmd-5369-2012, 2012.

Lambert, G., Le Roulley, J.-C., and Kritz, M.: Box model for radon transfers into the stratosphere, Tellus B, 42, 135-141, https://doi.org/10.1034/j.1600-0889.1990.00013.x, 1990.

Li, F., Vikhliaev, Y. V., Newman, P. A., Pawson, S., Perlwitz, J., Waugh, D. W., and Douglass, A. R.: Impacts of Interactive Stratospheric Chemistry on Antarctic and Southern Ocean Climate Change in the Goddard Earth Observing System, Version 5 (GEOS-5), J. Climate, 29, 3199-3218, https://doi.org/10.1175/JCLI-D-15-0572.1, 2016.

Lin, J.-T. and McElroy, M. B.: Impacts of boundary layer mixing on pollutant vertical profiles in the lower troposphere: Implications to satellite remote sensing, Atmos. Environ., 44, 17261739, 2010.

Lin, S.-J. and Rood, R. B.: Multidimensional flux-form semiLagrangian transport schemes, Mon. Weather Rev., 124, 20462070, 1996.

Liu, H., Jacob, D. J., Bey, I., and Yantosca, R. M.: Constraints from ${ }^{210} \mathrm{~Pb}$ and ${ }^{7} \mathrm{Be}$ on wet deposition and transport in a global threedimensional chemical, J. Geophys. Res., 106, 12109-12128, 2001.

Liu, S., McAfee, J., and Cicerone, R.: Radon 222 and tropospheric vertical transport, J. Geophys. Res.-Atmos., 89, 72917297, 1984.

Lock, A., Brown, A., Bush, M., Martin, G., and Smith, R.: A new boundary layer mixing scheme. Part I: Scheme description and single-column model tests, Mon Weather Rev., 128, 3187-3199, 2000.

Long, M. S., Yantosca, R., Nielsen, J. E., Keller, C. A., da Silva, A., Sulprizio, M. P., Pawson, S., and Jacob, D. J.: Development of a grid-independent GEOS-Chem chemical transport model (v9-02) as an atmospheric chemistry module for Earth system models, Geosci. Model Dev., 8, 595-602, https://doi.org/10.5194/gmd-8-595-2015, 2015.

Louis, J., Tiedke, M., and Geleyn, M.: A short history of the PBL parameterization at ECMWF, paper presented at, in: ECMWF Workshop on Planetary Boundary Layer Parameterization, Eur. Cent. for Medium-Range Weather Forecasts, Reading, UK, 1982.

Molod, A., Takacs, L., Suarez, M., and Bacmeister, J.: Development of the GEOS-5 atmospheric general circulation model: evolution from MERRA to MERRA2, Geosci. Model Dev., 8, 1339-1356, https://doi.org/10.5194/gmd-8-1339-2015, 2015.
Moorthi, S. and Suarez, M. J.: Relaxed Arakawa-Schubert. A parameterization of moist convection for general circulation models, Mon. Weather Rev., 120, 978-1002, 1992.

Oman, L. D. and Douglass, A. R.: Improvements in total column ozone in GEOSCCM and comparisons with a new ozonedepleting substances scenario, J. Geophys. Res.-Atmos., 119, 5613-5624, https://doi.org/10.1002/2014JD021590, 2014.

Ott, L., Bacmeister, J., Pawson, S., Pickering, K., Stenchikov, G., Suarez, M., Huntrieser, H., Loewenstein, M., Lopez, J., and Xueref-Remy, I.: Analysis of convective transport and parameter sensitivity in a single column version of the Goddard earth observation system, version 5, general circulation model, J. Atmos. Sci., 66, 627-646, 2009.

Putman, W. M. and Lin, S.-J.: Finite-volume transport on various cubed-sphere grids, J. Comput. Phys., 227, 55-78, 2007.

Rasch, P., Mahowald, N., and Eaton, B.: Representations of transport, convection, and the hydrologic cycle in chemical transport models: Implications for the modeling of short-lived and soluble species, J. Geophys. Res.-Atmos., 102, 28127-28138, 1997.

Rienecker, M., Suarez, M., Todling, R., Bacmeister, J., Takacs, L., Liu, H., Gu, W., Sienkiewicz, M., Koster, R., Gelaro, R., et al.: The GEOS-5 data assimilation system-documentation of versions 5.0. 1, 5.1. 0, NASA Tech Rep. TM-2007, 104606, 2008.

Rienecker, M. M., Suarez, M. J., Gelaro, R., Todling, R., Bacmeister, J., Liu, E., Bosilovich, M. G., Schubert, S. D., Takacs, L., Kim, G.-K., Bloom, S., Chen, J., Collins, D., Conaty, A., da Silva, A., Gu, W., Joiner, J., Koster, R. D., Lucchesi, R., Molod, A., Owens, T., Pawson, S., Pegion, P., Redder, C. R., Reichle, R., Robertson, F. R., Ruddick, A. G., Sienkiewicz, M., and Woollen, J.: MERRA: NASA's Modern-Era Retrospective Analysis for Research and Applications, J. Climate, 24, 3624-3648, https://doi.org/10.1175/JCLI-D-11-00015.1, 2011.

Rienecker, M. M., El Akkraoui, A., Todling, R., Whitaker, J., and Parrish, D. K. D.: Global Modeling and Assimilation Office Annual Report and Research Highlights 2011-2012, NASA Technical Report, https://ntrs.nasa.gov/search.jsp?R=20130008574 (last access: 11 May 2017), 2012.

Rotman, D. A., Atherton, C. S., Bergmann, D. J., Cameron-Smith, P. J., Chuang, C. C., Connell, P. S., Dignon, J. E., Franz, A., Grant, K. E., Kinnison, D. E., Molenkamp, C. R., Proctor, D. D., and Tannahill, J. R.: IMPACT, the LLNL 3-D global atmospheric chemical transport model for the combined troposphere and stratosphere: Model description and analysis of ozone and other trace gases, J. Geophys. Res.-Atmos., 109, D04303, https://doi.org/10.1029/2002JD003155, 2004.

Strode, S. A., Duncan, B. N., Yegorova, E. A., Kouatchou, J., Ziemke, J. R., and Douglass, A. R.: Implications of carbon monoxide bias for methane lifetime and atmospheric composition in chemistry climate models, Atmos. Chem. Phys., 15, 11789-11805, https://doi.org/10.5194/acp-15-11789-2015, 2015.

Wang, Y. X., McElroy, M. B., Jacob, D. J., and Yantosca, R. M.: A nested grid formulation for chemical transport over Asia: Applications to CO, J. Geophys. Res.-Atmos., 109, D22307, https://doi.org/10.1029/2004JD005237, 2004. 
Wu, S., Mickley, L. J., Jacob, D. J., Logan, J. A., Yantosca, R. M., and Rind, D.: Why are there large differences between models in global budgets of tropospheric ozone?, J. Geophys. Res.-Atmos., 112, d05302, https://doi.org/10.1029/2006JD007801, 2007.
Zhang, B., Liu, H., Crawford, J. H., Fairlie, T. D., Chen, G., Dibb, J. E., Shah, V., Sulprizio, M., and Yantosca, B.: Constraints from airborne ${ }^{210} \mathrm{~Pb}$ observations on aerosol scavenging and lifetime in a global chemical transport model, presented at 97th AMS Annual Meeting, 22-26 January 2017, Seattle, WA, 2017. 